\title{
Guest-host interactions in the alkaline bleaching of triphenylmethane dyes catalysed by $\beta$-cyclodextrin
}

\author{
V RAJ, A SARATHI, T CHANDRAKALA, S DHANALAKSHMI, R SUDHA and \\ K RAJASEKARAN* \\ Post Graduate and Research Department of Chemistry (DST-FIST Sponsored), \\ Virudhunagar Hindu Nadars' Senthikumara Nadar College, Virudhunagar 626001 \\ e-mail: krsekaran@yahoo.com
}

MS received 18 October 2008; revised 20 April 2009; accepted 28 April 2009

\begin{abstract}
The rates of alkaline bleaching of triphenylmethane dyes crystal violet $(\mathrm{CV})$, malachite green (MG) and rosaniline (RA) have been measured spectrophotometrically in an aqueous medium at $30^{\circ} \mathrm{C}$ in the presence of $\beta$-cyclodextrin (CD). At lower concentrations of $\mathrm{CD}$, CV forms productive $1: 1(\mathrm{G}: \mathrm{H})$ complex. At higher concentrations of $\mathrm{CD}$, it forms unproductive $1: 2(\mathrm{G}: \mathrm{H})$ complex. For the bleaching of $\mathrm{MG}, \mathrm{CD}$ accelerates or decelerates the rate depending on $\mathrm{pH}$ of the medium by forming $1: 1(\mathrm{G}: \mathrm{H})$ inclusion complex. Analysis of rate data shows that MG undergoes fading by mixed order process. CD decelerates the water reaction and accelerates hydroxide ion reaction. In the case of RA, both water reaction as well as hydroxide ion reaction are retarded by $\mathrm{CD}$ by the formation of inclusion complex.
\end{abstract}

Keywords. Crystal violet; malachite green; rosaniline; $\beta$-cyclodextrin; guest-host interactions.

\section{Introduction}

$\beta$-Cyclodextrin (CD) consists of seven $\alpha-(1,4)$ linked D-glycopyranose units forming a conical cylinder. The seven primary hydroxy groups are situated at the narrower end of the cylinder and fourteen secondary hydroxy groups form the wider rim. ${ }^{1,2} \mathrm{CD}$ forms inclusion complexes through non-covalent interactions with molecules of specific size and shape. The main factors affecting the stability of the inclusion complexes are: ${ }^{3}$ van der Walls interaction; hydrophobic interactions; hydrogen bonding; field effects. The stability of cyclodextrin complexes in solution, covalent-catalysis and field effects on organic reactions are reviewed. ${ }^{4,5}$ The well-defined cavity of $\mathrm{CD}$ has been frequently used as micro reactor which can catalyse or inhibit organic reactions by including the substrate in the cavity. ${ }^{6,7}$ The effects of $C D$ on chemical reaction can arise in a number of ways:

(i) CD can hide certain parts of guest molecule and expose other parts

(ii) they can change the conformation of the guest

*For correspondence (iii) their lipophilic cavity provides a non-polar medium for the guest within polar solvents

(iv) the $\mathrm{OH}$ groups of $\mathrm{CD}$ can participate in the reaction either directly as bases or nucleophiles.

Bleaching of triphenylmethane dyes is useful for studying chemical reactivity in organized media. In the present study, effect of $\beta$-cyclodextrin on the bleaching rates of triphenylmethane dyes crystal violet $(\mathrm{CV})$, malachite green $(\mathrm{MG})$ and rosaniline (RA) have been investigated in alkaline medium with a view to understand the guest-host interaction in these system.

\section{Experimental}

The dyes are all commercial samples. $\beta$-cyclodextrin from Fluka was dried at $95^{\circ} \mathrm{C}$ and used. Doubly distilled water was used for all the kinetic measurements. Carbonate free $\mathrm{NaOH}$ solutions were prepared by washing sodium hydroxide pellets (AR) repeatedly with water and standardised by potassium hydrogen phthalate standard. In the reaction medium $\mathrm{pH}$ was maintained by borax-borate buffers. All the pH measurements were made in Philips $\mathrm{pH}$ meter. All the kinetic measurements were made in an aque- 
ous system at $30^{\circ} \mathrm{C}$. The rates of bleaching of the dyes were measured by monitoring the OD of the solution at the $\lambda_{\max }$ of the dye $(\mathrm{CV}=602 \mathrm{~nm}$; $\mathrm{MG}=634 \mathrm{~nm} ; \mathrm{RA}=543 \mathrm{~nm}$ ) using Perkin-Elmer Hitachi 200-20 UV-Visible spectrophotometer provided with thermostatic cell holder. Concentration of the dyes ca $2 \times 10^{-5} \mathrm{M}$. The pseudo first-order rate constants, $k_{\mathrm{obs}}$, were evaluated from the plot of $\log A_{\mathrm{t}}$ versus time by the method of least squares $\left(A_{\mathrm{t}}\right.$ is the absorbance of the solution at time ' $t$ '). The bleaching of the dye is almost complete under the reaction conditions employed.

\section{Results and discussion}

\subsection{Bleaching of crystal violet $(\mathrm{CV})$}

The bleaching of triphenylmethane dyes is due to the formation of colourless carbinol by the nucleophilic attack of $\mathrm{H}_{2} \mathrm{O}$ and $\mathrm{OH}^{-}$on the dye cation.

$$
\mathrm{Ar}_{3} \mathrm{C}^{+} \stackrel{\mathrm{H}_{2} \mathrm{O}}{\mathrm{OH}} \mathrm{Ar}_{3} \mathrm{COH}
$$

The rate law for the above reaction is

$$
k_{\mathrm{obs}}=k_{\mathrm{H}_{2} \mathrm{O}}+k_{\mathrm{OH}}\left[\mathrm{OH}^{-}\right]
$$

where $k_{\mathrm{H}_{2} \mathrm{O}}$ is the pseudo first-order rate constant for water reaction and $k_{\mathrm{OH}}$ is the second order rate constant for hydroxide ion reaction.

The rates of bleaching of CV was measured spectrophotometrically in the absence of $\mathrm{CD}$ in varying

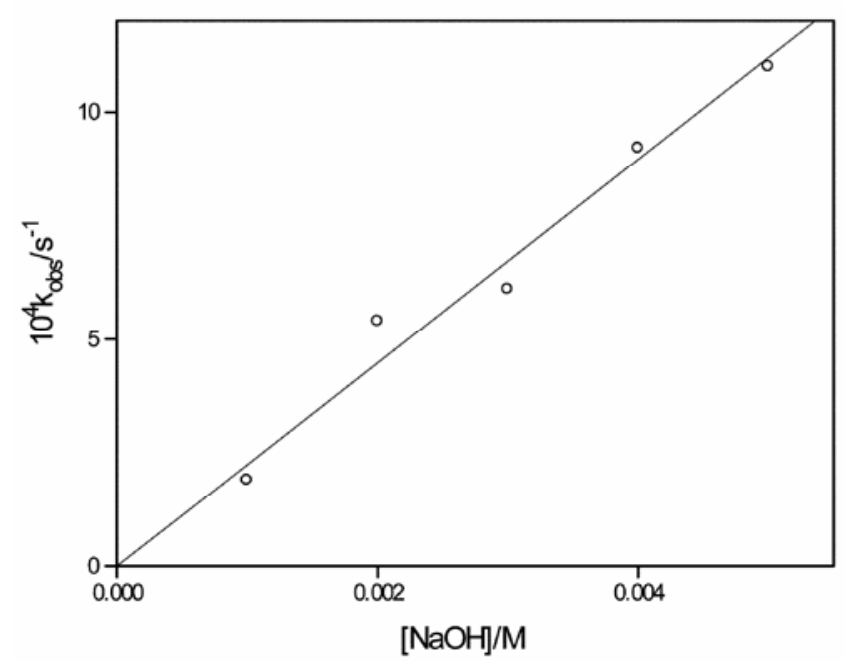

Figure 1. Variation of $k_{\mathrm{obs}}$ with $\left[\mathrm{OH}^{-}\right]$for bleaching of crystal violet at $30^{\circ} \mathrm{C}$. amount of $\mathrm{NaOH}$. Figure 1 is the plot of $k_{\text {obs }}$ versus $\left[\mathrm{OH}^{-}\right]$, which is linear with negligible intercept and a slope value of $0 \cdot 22$. Under the reaction conditions employed $k_{\mathrm{H}_{2} \mathrm{O}} \approx 0$ and $k_{\mathrm{OH}}=0.22 \mathrm{~mol} \mathrm{dm}^{-3} \mathrm{~s}^{-1}$. Ritchie et $a l^{8}$ reported $\left(k_{2}=0.22 \mathrm{~mol} \mathrm{dm}^{-3} \mathrm{~s}^{-1}\right)$ for fading of $\mathrm{CV}$.

The rate of bleaching was also measured in the presence of varying amount of CD in 0.001, 0.003 and $0.005 \mathrm{M} \mathrm{NaOH}$. Figure 2 is the plot of $k_{\text {obs }}$ versus [CD] for the bleaching of $\mathrm{CV}$ in $0.001 \mathrm{M} \mathrm{NaOH}$ at $30^{\circ} \mathrm{C}$. Initially $k_{\mathrm{obs}}$ value increases with an increase of $[C D]$, reaches a maximum and then decreases. Similar results were obtained in 0.003 and $0.005 \mathrm{M} \mathrm{NaOH}$. Such rate maxima were reported in the cleavage of esters by $\mathrm{CD}^{9,10}$ and in peroxide bleaching of Green $\mathrm{S}^{11}$ in the presence of CD. This type of rate behaviour is due to the formation of productive $1: 1(\mathrm{G}: \mathrm{H})$ complex at lower concentrations of $\mathrm{CD}$ and formation of unproductive $1: 2(\mathrm{G}: \mathrm{H})$ complex at higher concentrations of $\mathrm{CD}$.

The reaction proceeding through $1: 1$ complex can be represented as shown in scheme 1 .

The rate law for the scheme 1 is

$$
k_{\mathrm{obs}}=\frac{k_{\mathrm{u}} K_{\mathrm{D}}+k_{\mathrm{c}}[\mathrm{CD}]}{K_{\mathrm{D}}+[\mathrm{CD}]},
$$

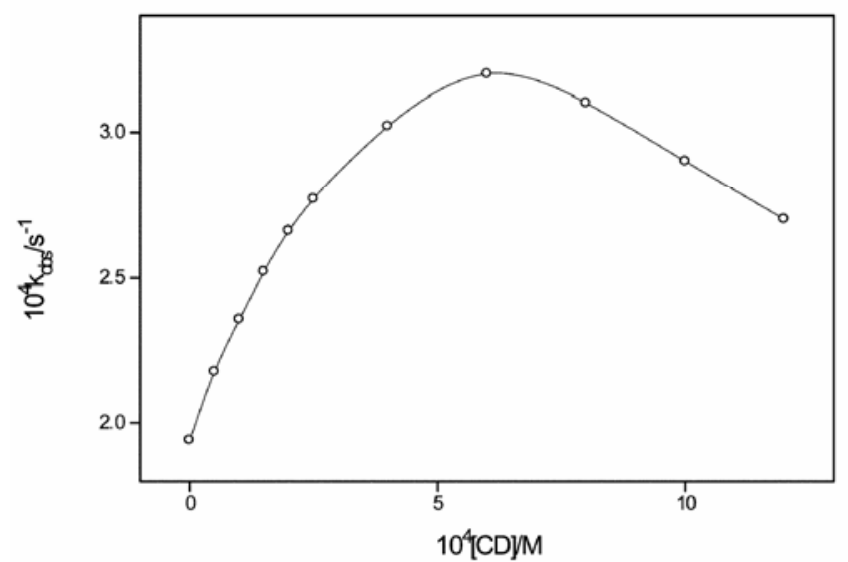

Figure 2. Effect of $[\mathrm{CD}]$ on bleaching rate of crystal violet in $0.001 \mathrm{M} \mathrm{NaOH}$ at $30^{\circ} \mathrm{C}$.

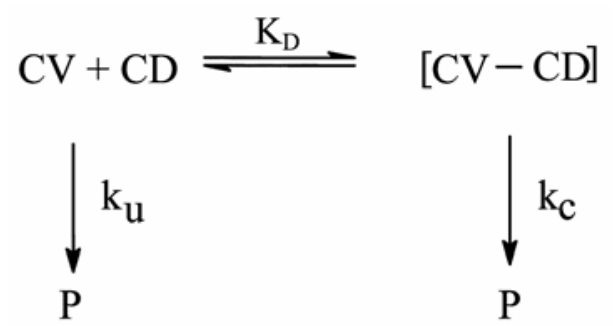

Scheme 1. 
Table 1. Rate-constant and complex-dissociation constant for $[\mathrm{CV}-\mathrm{CD}]$ complex at $30^{\circ} \mathrm{C}$.

\begin{tabular}{lcccc}
\hline$[\mathrm{NaOH}] / \mathrm{M}$ & $k_{\mathrm{u}} \times 10^{4}\left(\mathrm{~s}^{-1}\right)$ & $k_{\mathrm{c}} \times 10^{4}\left(\mathrm{~s}^{-1}\right)$ & $k_{\mathrm{c}} / k_{\mathrm{u}}$ & $K_{\mathrm{D}} \times 10^{4}\left(\mathrm{~mol} \mathrm{dm}^{-3}\right)$ \\
\hline 0.001 & 1.9 & $4 \cdot 0$ & $2 \cdot 1$ & $4 \cdot 1$ \\
$0 \cdot 002$ & $5 \cdot 4$ & $10 \cdot 0$ & $1 \cdot 9$ & 4.6 \\
0.003 & $6 \cdot 1$ & $13 \cdot 8$ & $2 \cdot 3$ & $3 \cdot 3$ \\
$0 \cdot 100^{*}$ & $162 \cdot 0$ & $240 \cdot 0$ & 1.5 & 3.6 \\
\hline
\end{tabular}

*Data from ref. 12

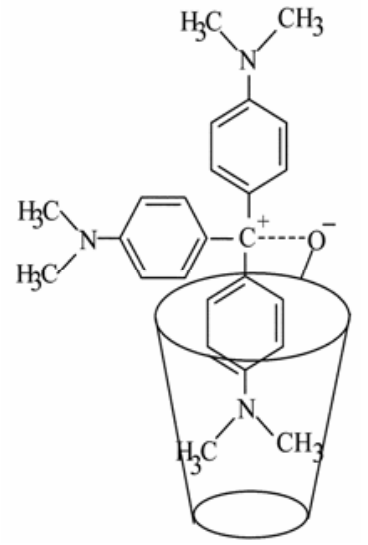

Figure 3. $[\mathrm{CV}-\mathrm{CD}] 1: 1$ inclusion complex.

where $k_{\mathrm{u}}$ and $k_{\mathrm{c}}$ are the rate constants for uncatalysed and catalysed path ways respectively and $K_{\mathrm{D}}$ is the dissociation constant of $[\mathrm{CV}-\mathrm{CD}]$ complex.

Equation (3) can be re-arranged to (4)

$$
\left(k_{\mathrm{obs}}-k_{\mathrm{u}}\right)=-K_{\mathrm{D}} \frac{\left(k_{\mathrm{obs}}-k_{\mathrm{u}}\right)}{[\mathrm{CD}]}+\left(k_{\mathrm{c}}-k_{\mathrm{u}}\right) .
$$

By fitting the rate data in raising portion of the curve, employing (4), $k_{\mathrm{c}}$ and $K_{\mathrm{D}}$ value for [CV-CD] complexes were evaluated and summarized in table 1.

For the purpose of comparison, the literature data reported by Rio et $a l^{12}$ is also included in the table 1 . The $K_{\mathrm{D}}$ value evaluated by us is close to that of the literature value. For $[\mathrm{CV}-\mathrm{CD}] 1: 1$ complex, Liu et $a l^{13}$ have reported $K_{\mathrm{D}}$ as $5.3 \times 10^{-4} \mathrm{~mol} \mathrm{dm}^{-3}\left(25^{\circ} \mathrm{C}\right.$ $\mathrm{pH}=7 \cdot 2$ ) by spectrophotometric method. The rate acceleration in CD catalysed reaction is usually measured by the ratio $k_{\mathrm{c}} / k_{\mathrm{u}}$. The data in table 1 show that $\mathrm{CD}$ accelerates the bleaching rate of $\mathrm{CV}$ marginally by formation of $1: 1(\mathrm{G}: \mathrm{H})$ complex. The structure of the inclusion complex of $\mathrm{CV}$ with $\mathrm{CD}$ has been proposed by Rio et $a l^{12}$ based on NMR spectral measurements. In the $[\mathrm{CV}-\mathrm{CD}]$ complex, the dye enters into the hydrophobic cavity through the wider rim. One phenyl group is accommodated within the CD cavity (figure 3 ). The secondary hydroxy group of CD is weakly acidic ${ }^{14}\left(\mathrm{pK}_{\mathrm{a}}=12 \cdot 2\right)$. Under alkaline condition, this hydroxy group is ionized. The nucleophilic attack of the ionized secondary hydroxy group of CD on the dye cation may be the reason for the rate acceleration. This is similar to the rate acceleration caused by CDs on the cleavage of phenyl esters. ${ }^{15}$

At higher concentrations of $\mathrm{CD}$, another aryl ring of CV may occupy the cavity of second CD molecule leading to $1: 2(\mathrm{G}: \mathrm{H})$ complex. Steric crowding around the reaction centre may retard the rate of the reaction.

\subsection{Bleaching of malachite green and rosaniline}

The rates of bleaching of malachite green (MG) and rosaniline (RA) were measured in $0.001 \mathrm{M} \mathrm{NaOH}$ and borax-borate buffers of several $\mathrm{pH}$ in the presence of varying amount of $\mathrm{CD}$. For malachite green, in $0.001 \mathrm{M} \mathrm{NaOH}, k_{\text {obs }}$ values increase with an increase of [CD]. In borax-borate buffers, the variation of $k_{\text {obs }}$ with [CD] is interesting. At $\mathrm{pH} 10$, 9.7 and $9.4, k_{\text {obs }}$ increases with increase of [CD]. At $\mathrm{pH} 9 \cdot 1, k_{\text {obs }}$ is insensitive to [CD]. At pH 8.8, $k_{\text {obs }}$ decreases with increase of [CD] (figure 4).

For RA, the rate of bleaching decreases with an increase of [CD] in $0.001 \mathrm{M} \mathrm{NaOH}$ (figure 5).

Similar rate retardation was observed in all the borax-borate buffers. By analysing the rate data in terms of (4), the apparent rate constants $k_{\mathrm{u}}^{\mathrm{a}}$ and $k_{\mathrm{c}}^{\mathrm{a}}$ and $K_{\mathrm{D}}$ values for [MG-CD] complex and [RA-CD] complex were evaluated (tables 2 and 3 ).

It is well-known that unlike $\mathrm{CV}$, bleaching of $\mathrm{MG}$ and RA is a mixed order process (i.e.) both water reaction and hydroxide ion reaction are significant. ${ }^{16}$ Therefore for bleaching of MG and RA, the following scheme 2 can be envisaged.

Both the complexed and uncomplexed dye undergo bleaching by reaction with $\mathrm{H}_{2} \mathrm{O}$ and hydroxide 
Table 2. Rate constants and equilibrium constants for the bleaching of MG in presence of $\mathrm{CD}$ at $30^{\circ} \mathrm{C}$.

\begin{tabular}{lcccc}
\hline $\mathrm{pH}^{*}$ & $k_{\mathrm{u}}^{\mathrm{a}} \times 10^{4}\left(\mathrm{~s}^{-1}\right)$ & $k_{\mathrm{c}}^{\mathrm{a}} \times 10^{4}\left(\mathrm{~s}^{-1}\right)$ & $k_{\mathrm{u}}^{\mathrm{a}} / k_{\mathrm{c}}^{\mathrm{a}}$ & $K_{\mathrm{D}} \times 10^{4}\left(\mathrm{dm}^{-3} \mathrm{~mol}\right)$ \\
\hline 8.8 & 3.9 & $3 \cdot 2$ & $0 \cdot 8$ & 2.7 \\
$9 \cdot 1$ & 4.7 & $4 \cdot 7$ & $1 \cdot 0$ & $\ldots \ldots$ \\
9.4 & 4.9 & 5.5 & $1 \cdot 1$ & $\ldots \ldots$ \\
9.7 & 5.8 & $6 \cdot 9$ & 1.2 & $\ldots \ldots$ \\
$10 \cdot 0$ & 7.8 & 13.5 & 1.7 & 5.4 \\
$0.001 \mathrm{M} \mathrm{NaOH}$ & 18.5 & 38.3 & $2 \cdot 0$ & $\ldots$ \\
\hline
\end{tabular}

*Borax-borate buffer

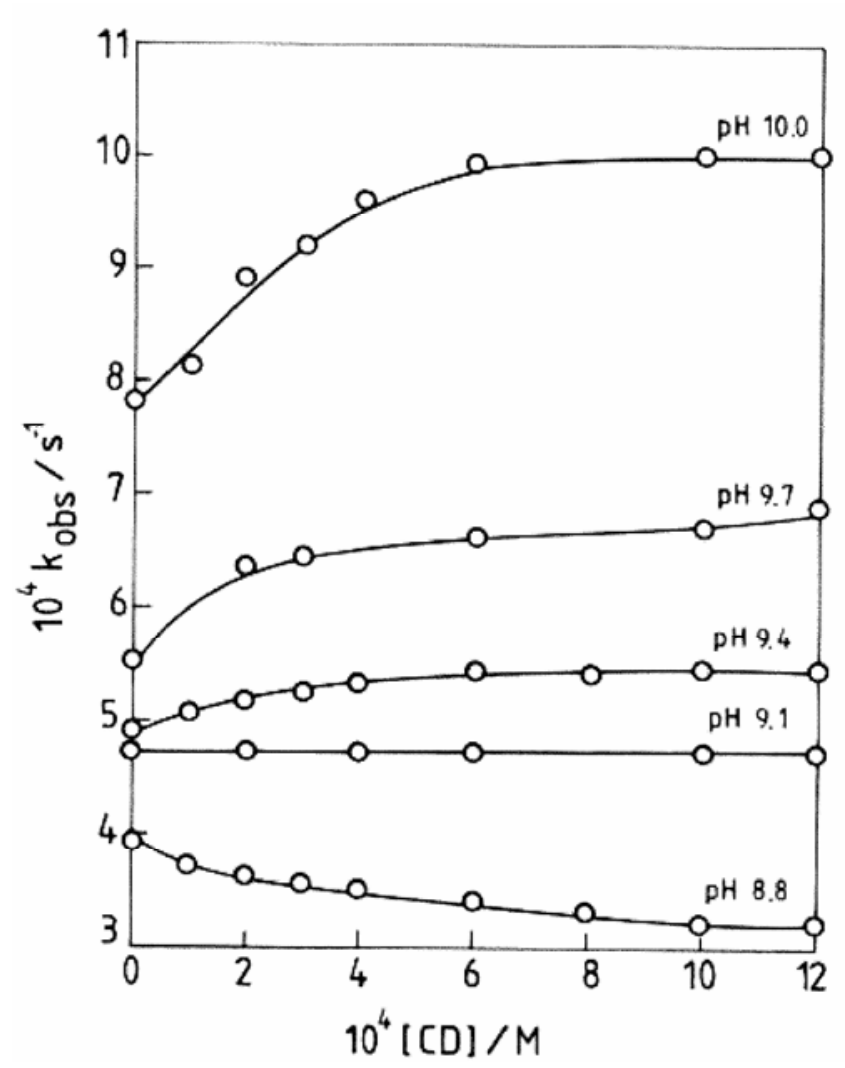

Figure 4. Variation of $k_{\mathrm{obs}}$ with [CD] for bleaching of malachite green in borax-borate buffers at $30^{\circ} \mathrm{C}$.

$$
\begin{aligned}
& \mathrm{DYE}+\mathrm{H}_{2} \mathrm{O} \stackrel{k_{\mathrm{u}}^{\mathrm{H}_{2} \mathrm{O}}}{\longrightarrow} \mathrm{P} \\
& \mathrm{DYE}+\mathrm{OH}^{-} \stackrel{k_{\mathrm{u}}^{\mathrm{OH}}}{\longrightarrow} \mathrm{P} \\
& \mathrm{DYE}+\mathrm{CD} \stackrel{K_{\mathrm{D}}}{\longrightarrow}[\mathrm{DYE}-\mathrm{CD}] \\
& {[\mathrm{DYE}-\mathrm{CD}] \stackrel{k_{\mathrm{c}}^{\mathrm{H}} \mathrm{O}}{\longrightarrow} \mathrm{P}} \\
& {[\mathrm{DYE}-\mathrm{CD}] \stackrel{k_{\mathrm{c}}^{\mathrm{OH}}}{\longrightarrow} \mathrm{P}} \\
& \mathrm{DYE}=\mathrm{MG} / \mathrm{RA}
\end{aligned}
$$

Scheme 2.

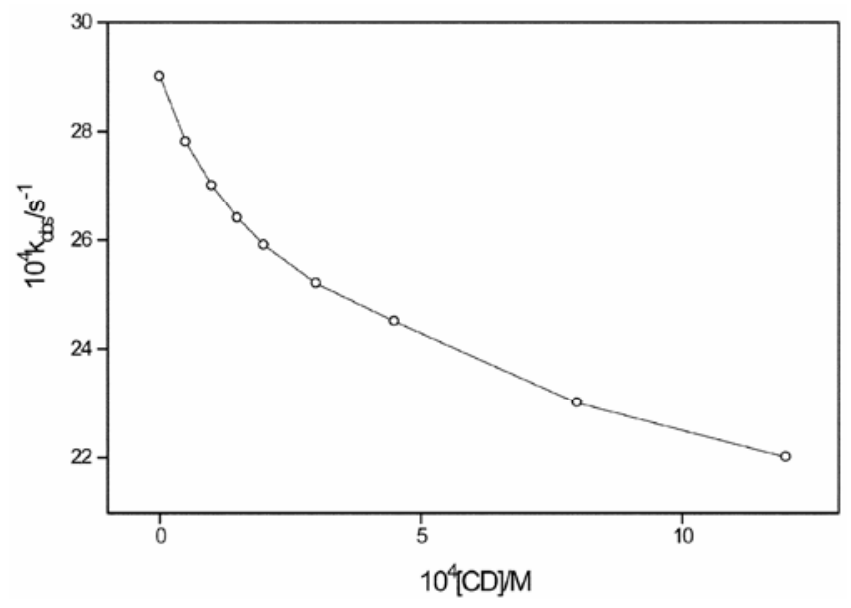

Figure 5. Effect of $[\mathrm{CD}]$ on the rate of bleaching of rosaniline in $0.001 \mathrm{M} \mathrm{NaOH}$ at $30^{\circ} \mathrm{C}$.

ion. The $k_{\mathrm{a}}{ }^{\mathrm{u}}$ and $k_{\mathrm{a}}{ }^{\mathrm{c}}$ values reported in tables 2 and 3 are all composite rate constants and can be expressed in terms of (5) and (6).

$$
\begin{aligned}
& k_{\mathrm{u}}^{\mathrm{a}}=k_{\mathrm{u}}^{\mathrm{H}_{2} \mathrm{O}}+k_{\mathrm{u}}^{\mathrm{OH}}\left[\mathrm{OH}^{-}\right] \\
& k_{\mathrm{c}}^{\mathrm{a}}=k_{\mathrm{c}}^{\mathrm{H}_{2} \mathrm{O}}+k_{\mathrm{c}}^{\mathrm{OH}}\left[\mathrm{OH}^{-}\right] .
\end{aligned}
$$

The values of $k_{\mathrm{u}}^{\mathrm{a}}$ and $k_{\mathrm{c}}^{\mathrm{a}}$ are dependent of $\mathrm{pH}$. They are fitted in terms of equations 5 and 6 , by the method of least squares and $\mathrm{pH}$ independent rate constants $k_{\mathrm{u}}^{\mathrm{H}_{2} 0}, k_{\mathrm{u}}^{\mathrm{OH}}, k_{\mathrm{c}}^{\mathrm{H}_{2} 0}$ and $k_{\mathrm{c}}^{\mathrm{OH}}$ for the uncomplexed and complexed dye cations for water and hydroxide reactions of $\mathrm{MG}$ and $\mathrm{RA}$ are evaluated and presented in table 4.

Examination of data in table 4 shows that CD accelerates hydroxide ion reaction with $\mathrm{MG}$ but it decelerates the water reaction. The rate acceleration in hydroxide ion reaction may be explained as in the case of $\mathrm{CV}$. One of the aryl rings containing $-\mathrm{N}\left(\mathrm{CH}_{3}\right)_{2}$ substituent (which is more hydrophobic 
Table 3. Rate constants and equilibrium constants for the bleaching of RA in presence of $\mathrm{CD}$ at $30^{\circ} \mathrm{C}$.

\begin{tabular}{|c|c|c|c|c|}
\hline $\mathrm{pH}^{*}$ & $k_{\mathrm{u}}^{\mathrm{a}} \times 10^{4}\left(\mathrm{~s}^{-1}\right)$ & $k_{\mathrm{c}}^{\mathrm{a}} \times 10^{4}\left(\mathrm{~s}^{-1}\right)$ & $k_{\mathrm{u}}^{\mathrm{a}} / k_{\mathrm{c}}^{\mathrm{a}}$ & $K_{\mathrm{D}} \times 10^{4} \mathrm{dm}^{-3} \mathrm{~mol}$ \\
\hline $8 \cdot 8$ & $7 \cdot 1$ & $3 \cdot 8$ & $0 \cdot 54$ & $\ldots \ldots$ \\
\hline $9 \cdot 1$ & $8 \cdot 3$ & $5 \cdot 6$ & 0.67 & $\ldots \ldots$ \\
\hline $9 \cdot 4$ & $8 \cdot 6$ & 5.9 & $0 \cdot 68$ & $\ldots \ldots$ \\
\hline 9.7 & $9 \cdot 2$ & $6 \cdot 3$ & $0 \cdot 68$ & $\ldots \ldots$ \\
\hline $10 \cdot 0$ & $12 \cdot 6$ & $9 \cdot 0$ & 0.71 & $\cdots$ \\
\hline $0.001 \mathrm{M} \mathrm{NaOH}$ & $29 \cdot 0$ & $22 \cdot 0$ & $0 \cdot 76$ & $2 \cdot 4$ \\
\hline
\end{tabular}

*Borax-borate buffer

Table 4. $\mathrm{pH}$ independent rate constants for the bleaching of complexed and uncomplexed dyes (MG and RA) at $30^{\circ} \mathrm{C}$.

\begin{tabular}{|c|c|c|c|c|}
\hline \multirow[t]{2}{*}{ Malachite green } & Water reaction & $\begin{array}{c}k_{\mathrm{u}}^{\mathrm{H}_{2} \mathrm{O}} \\
3 \cdot 9 \times 10^{-4} \mathrm{~s}^{-1}\end{array}$ & $\begin{array}{c}k_{\mathrm{c}}^{\mathrm{H}_{2} \mathrm{O}} \\
2.7 \times 10^{-4} \mathrm{~s}^{-1}\end{array}$ & $\begin{array}{c}k_{\mathrm{c}}^{\mathrm{H}_{2} \mathrm{O}} / k_{\mathrm{u}}^{\mathrm{H}_{2} \mathrm{O}} \\
0.7\end{array}$ \\
\hline & $\mathrm{OH}^{-}$reaction & $\begin{array}{c}k_{\mathrm{u}}^{\mathrm{OH}} \\
10 \cdot 4 \mathrm{dm}^{3} \mathrm{~mol}^{-1} \mathrm{~s}^{-1}\end{array}$ & $\begin{array}{c}k_{\mathrm{c}}^{\mathrm{OH}} \\
3 \cdot 9 \mathrm{dm}^{3} \mathrm{~mol}^{-1} \mathrm{~s}^{-1}\end{array}$ & $\begin{array}{c}k_{\mathrm{c}}^{\mathrm{OH}} / k_{\mathrm{u}}^{\mathrm{OH}} \\
2 \cdot 7\end{array}$ \\
\hline \multirow[t]{2}{*}{ Rosanaline } & Water reaction & $\begin{array}{c}k_{\mathrm{u}}^{\mathrm{H}_{2} \mathrm{O}} \\
8 \cdot 3 \times 10^{-4} \mathrm{~s}^{-1}\end{array}$ & $\begin{array}{c}k_{\mathrm{c}}^{\mathrm{H}_{2} \mathrm{O}} \\
5.4 \times 10^{-4} \mathrm{~s}^{-1}\end{array}$ & $\begin{array}{c}k_{\mathrm{c}}^{\mathrm{H}_{2} \mathrm{O}} / k_{\mathrm{u}}^{\mathrm{H}_{2} \mathrm{O}} \\
0.65\end{array}$ \\
\hline & $\mathrm{OH}^{-}$reaction & $\begin{array}{c}k_{\mathrm{u}}^{\mathrm{OH}} \\
2 \cdot 1 \mathrm{dm}^{3} \mathrm{~mol}^{-1} \mathrm{~s}^{-1}\end{array}$ & $\begin{array}{c}k_{\mathrm{c}}^{\mathrm{OH}} \\
1.7 \mathrm{dm}^{3} \mathrm{~mol}^{-1} \mathrm{~s}^{-1}\end{array}$ & $\begin{array}{c}k_{\mathrm{c}}^{\mathrm{OH}} / k_{\mathrm{u}}^{\mathrm{OH}} \\
0 \cdot 80\end{array}$ \\
\hline
\end{tabular}

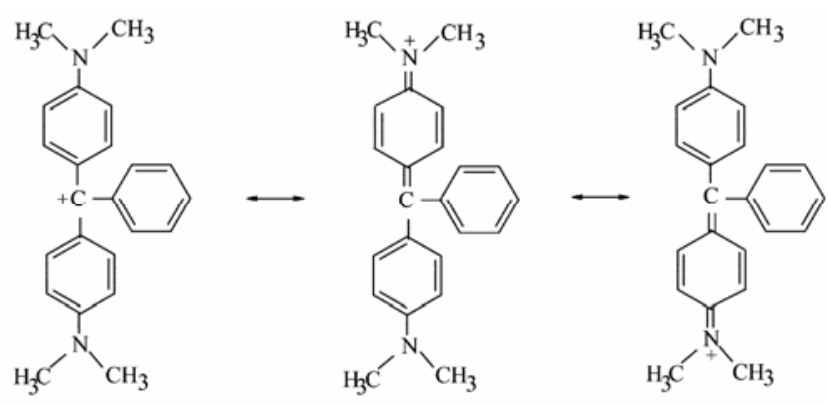

Figure 6. Delocalisation of positive charge on central carbon of $\mathrm{MG}$ into the aromatic rings.

than the unsubstituted phenyl ring) is incorporated into the hydrophobic cavity of CD. The ionized secondary hydroxy group of CD catalyses the bleaching rate.

The rate retardation in water reaction may be explained as follows: due to direct conjugation between the alkylamino substituents and the positive charge on the central carbon atom contiguous to aromatic rings, the positive charge is delocalized over the aromatic rings (figure 6).

The approach of the nucleophile, water, brings about a change in the hybridisation of the central atom and the activation process brings about signifi- cant attenuation of direct conjugation of carbonium ion with ring substitutents (i.e.) the approach of nucleophile results in enhancement of positive charge density on central carbon. The negative volume of activation $^{17,18}$ observed for MG-water reaction is in accordance with the formation of new bond between the substrate and nucleophile by the localization of the initially dispersed charge on reactant.

For such reactions, the rate of the reaction will decrease as the polarity of the solvent decreases. The rate retardation by inclusion in the CD cavity can be explained by a micro solvent effect. The hydrophobic cavity of CD is similar to a solvent of low dielectric constant. In the inclusion complex, the dye is inserted into the non-polar region within the ring of sugar residues and is expected to decelerate the fading process just as it would be if the medium were less polar by the addition of an organic solvent of low dielectric constant.

The interior of micelles are hydrophobic, similar to cavity of CD. Dynstee et $a l^{19}$ showed that for MG, the water reaction is retarded by both cationic micelle and anionic micelle. This is attributed to the fact that for water reaction the transition state resembles that of the reactant $\mathrm{Ar}_{3} \mathrm{C}^{+}$and may be represented as $\left[\mathrm{Ar}_{3} \mathrm{C} \ldots \mathrm{OH}_{2}\right]^{+}$. Koth Wada et al ${ }^{20}$ re- 
ported that in fading of triphenylmethane dye addition of alcohol retards the rate. There is similarity between CD catalysed and micellar catalysed reaction of bleaching of the triphenylmethane dyes for water reaction.

For RA, CD decelerates the rate of both water and hydroxide ion reaction (table 4). This is contrary to the results obtained for $\mathrm{CD}-\mathrm{MG}$ reaction.

The aryl rings of $\mathrm{CV}$ and $\mathrm{MG}$ contain the hydrophobic $-\mathrm{N}\left(\mathrm{CH}_{3}\right)_{2}$ group. But in $\mathrm{RA}$, the aryl ring contains the hydrophilic $-\mathrm{NH}_{2}$ group. The amino group of the aryl ring can form $\mathrm{H}$-bond with hydroxy group of $\mathrm{CD}^{21}$ Usually the host-guest hydrogen bondings come from the primary hydroxy groups $(\mathrm{C}-6)$ of $\mathrm{CD}$ which are flexible and can rotate about $\mathrm{C}(5)-\mathrm{C}(6)$ bond. In contrast the secondary hydroxy groups on $\mathrm{C}(2)$ and $\mathrm{C}(6)$ are rigid. Further, attractive $-\mathrm{N}-\mathrm{H} \ldots \mathrm{O}$ interactions can occur between the included guest and the array of lone pairs on oxygen ${ }^{22}$ atom of $\mathrm{CD}$. These H-bonding plays significant role in the mode of insertion of guest molecule inside the $\mathrm{CD}$ cavity. ${ }^{23}$

Connors et $a l^{24}$ suggested that benzoic acid bind $\alpha-\mathrm{CD}$ with the $\mathrm{COOH}$ at the narrow end of the cavity. But in benzoate ion, the carboxylate moiety is positioned at the wider secondary hydroxy end of CD

The wide rim of the CD is distinctly hydrophilic while the narrow rim bearing the primary hydroxy group is intensely hydrophobic. ${ }^{25}$ The dye cation may form an inclusion complex in which $\mathrm{NH}_{2}$ group may be positioned either nearer to narrow rim or wider rim of $\mathrm{CD}$. From the kinetic data alone it will not be possible to predict the mode of insertion of dye.

The stabilization of the ground state by $\mathrm{H}$ bonding may be the reason for the reduced reactivity of the complexed dye in the case of RA.

\section{Conclusion}

Fading of crystal violet is second order process. At low concentrations, $\mathrm{CD}$ accelerates the rate of bleaching of $\mathrm{CV}$ by forming productive $1: 1(\mathrm{G}: \mathrm{H})$ complex. At higher concentrations of $\mathrm{CD}$, unproductive $1: 2(\mathrm{G}: \mathrm{H})$ complex is formed. Bleaching of malachite green and rosanaline is a mixed order process. For MG, CD accelerates the hydroxide ion reaction and decelerates the water reaction by the formation of $1: 1(\mathrm{G}: \mathrm{H})$ complex. In the case of RA, CD decelerates both water and hydroxide ion reaction due to the stabilization of ground state by $\mathrm{H}$-bonding with the host.

\section{Acknowledgement}

The authors thank the Managing Board of Virudhunagar Hindu Nadars' Senthikumara Nadar College, Virudhunagar for financial assistance and research facilities.

\section{References}

1. Bender M and Komiyana M 1978 Cyclodextrin chemistry (New York: Springer-Verlag)

2. Wenz G and Angew 1994 Chem. Int. Ed. Egl. 33803

3. Inoue Y 1993 Ann. Rep. NMR Spectrosc. 2759

4. Connors K A 1997 Chem. Rev. 971325

5. Takahashi K 1998 Chem. Rev. 982013

6. Viola L and de Rossi R H 1999 Can. J. Chem. 77860

7. Granados A M and de Rossi R H $2001 \mathrm{~J}$. Org. Chem. 661548

8. Ritchie C D, Wright D J, Huang D S and Kamego $1975 \mathrm{~J}$. Am. Chem. Soc. 971163

9. Davies M D and Deary M E $1999 \mathrm{~J}$. Chem. Soc. Perkin Trans II 1027

10. Tee O S and Xian-Xian Du 1988 J. Org. Chem. 53 1839

11. Henri d'Hausen P, Tait C N and Davies D M $2002 J$. Chem. Soc. Perkin Trans II 398

12. Rio L G, Leis J R, Mefulo J C, Navarro-Vazquez A, Pe'rez-Jusle J and Rodriguez-Da-fonte P 2004 Langmuir 20606

13. Yu Liu, Bin Li, Chans-Chans You, Takehikowada and Yoshihisa Inove $2001 \mathrm{~J}$. Org. Chem. 66225

14. Tee O S, Mazza C and Xian-Xian Du $1990 \mathrm{~J}$. Org. Chem. 553603

15. Van Etten R L, Sebastian J F, Clowes G A and Bender M L $1967 \mathrm{~J}$. Am. Chem. Soc. 893242

16. Ritchie C D, Skinnan G A and Badding V G $1967 \mathrm{~J}$. Am. Chem. Soc. 892063

17. Obaid Hassan Abed and Neil Isaacs S 1983 J. Chem. Soc. Perkin Trans II 841

18. Le-Noble W J, Gebicka E and Sri Vastava S $1982 J$. Am. Chem. Soc. 1043153

19. Duynslee E F J and Grunwald E $1959 \mathrm{~J}$. Am. Chem. Soc. 814542

20. Patel M S, Kothwada D M and Nagar T N 2003 Asian J. Chem. 15202

21. Hamilton J A and Chen L Y $1988 \mathrm{~J}$. Am. Chem. Soc. 1105833

22. Steiner T and Saenger W 1992 J. Am. Chem. Soc. 114 10146

23. Yi Z P, Chen H L, Huary Z Z, Huang $\mathrm{G}$ and Yu J S 2000 J. Chem. Soc. Perkin Trans II 121

24. Connors K A, Lin S F and Wong A B 1982 J. Pharm. Sci. 71217

25. Lipkowitz K B 1998 Chem. Rev. 981829 